$\mathrm{Oz}$

$1-1-2014$

\title{
Hypothesizing a New Case Study House Program: A Systems Approach
}

Genevieve Baudoin

Kansas State University

Follow this and additional works at: https://newprairiepress.org/oz

Part of the Architecture Commons

(c) 1 (1) $\Theta$

This work is licensed under a Creative Commons Attribution-Noncommercial-No Derivative Works 4.0 License.

\section{Recommended Citation}

Baudoin, Genevieve (2014) "Hypothesizing a New Case Study House Program: A Systems Approach," Oz: Vol. 36. https://doi.org/10.4148/2378-5853.1526

This Article is brought to you for free and open access by New Prairie Press. It has been accepted for inclusion in Oz by an authorized administrator of New Prairie Press. For more information, please contact cads@k-state.edu. 


\section{Hypothesizing a New Case Study House Program A Systems Approach}

\section{Genevieve Baudoin}

In 1945, Arts and Architecture announced that they would be publishing the designs of eight case study houses that envisioned the "house-post war." These infamous Case Study Houses grew from an initial eight to thirty-six designs over twenty-two years-some built, some imagined. All of the designs were an effort to imagine a "contemporary" way of living, using new materials and construction techniques, with the backdrop of Southern California. While benefiting from a temperate climate, many of the houses tackled nearly impossible terrain, not only envisioning a new way of life, but also seemingly insurmountable places to live that still captured the beauty and accessibility of the outdoors. Over 50 years after these prototypes were invented, the time is ripe to not only re-envision the way we live, but reimagine where.

Suburban development has dramatically altered the American landscape-converting wilderness and farmland to a low-density manicured lawn-scape. An interesting quality of suburbs is their uneasy relationship with the complex natural environment these neighborhoods are built upon. This relationship is something cities take for granted until "disasters" (in quotes here because these events only become disasters when human life and property are threatened) cause millions of dollars in damage to the built environment, having literally built over forgotten waterways, coastlines, swamps, and floodplains. While much focus has been put on reinvigorating downtowns and promoting higher density living, the densification of a suburb is difficult to imagine without razing whole neighborhoods, a solution that could create similar problems under a new guise. Without tearing down existing neighborhoods, how can architects densify them?

Any new Case Study House (CSH) must acknowledge the invasive role new construction takes on in the environment. In trade for this invasive quality, a new CSH could act as steward: monitoring, adjusting, and responding to the hidden order of the landscape prior to the existing life of a neighborhood. A new $\mathrm{CSH}$ would be sited in impossible places: in the uneasy spaces suburbs have created to accommodate the dynamic and changeable forces of nature. As with the original Case Study Houses, a new CSH would respond to its climate, acknowledging the beauty and accessibility of the outdoors. Its materials and construction would take advantage of the novel, but also seek to capitalize on the infrastructural systems nested within suburban fabric. This will lead to an inevitably dynamic tectonic response, one that is on the one hand heavy, stereotomic and earth shaping, and on the other light, tectonic, and adaptable. The locale for a new $\mathrm{CSH}$ cannot remain confined to a single region but must strive to design to the idiosyncratic specificity of a place while recognizing the design challenges of integrat-

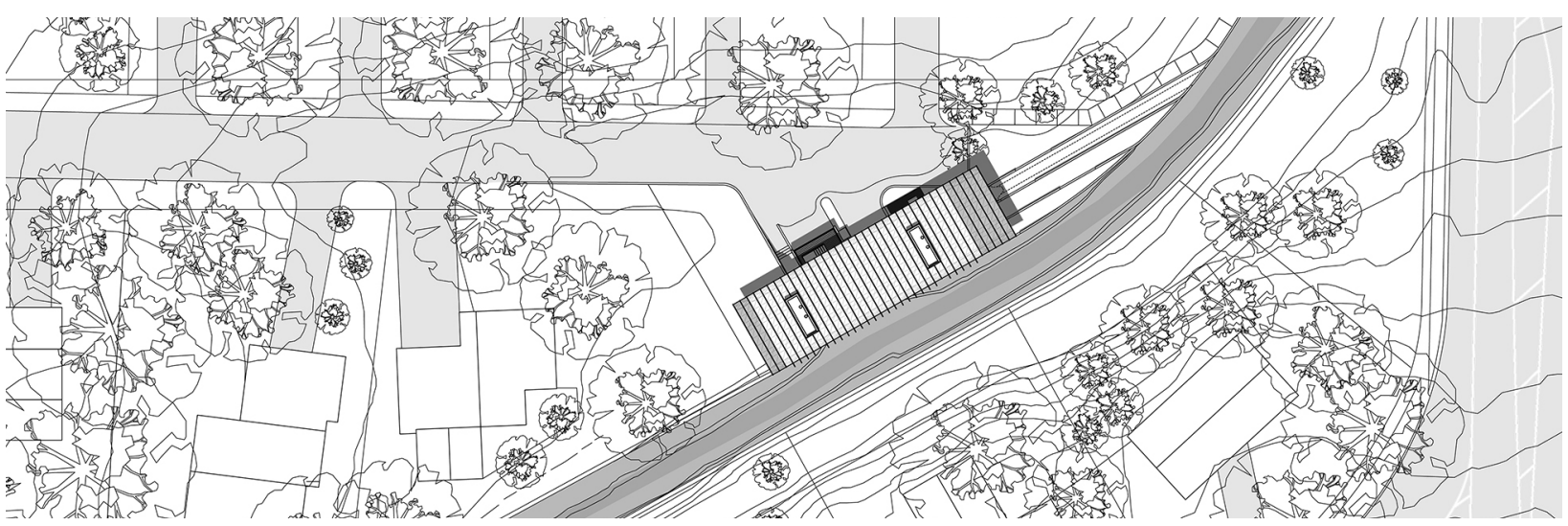

ing with a complex system of built and natural infrastructures.

\section{Case Study One (CS1): Kansas City-Cul de Sac}

Kansas City is one of the top $10 \mathrm{com}-$ muter cities in America. In 2011, Kiplinger stated that the average Kansas City commute was 22.6 minutes and 9.16 miles, while only $1.7 \%$ of the population used public transit. Pitch, a local Kansas City newspaper, compared this to the worst city for
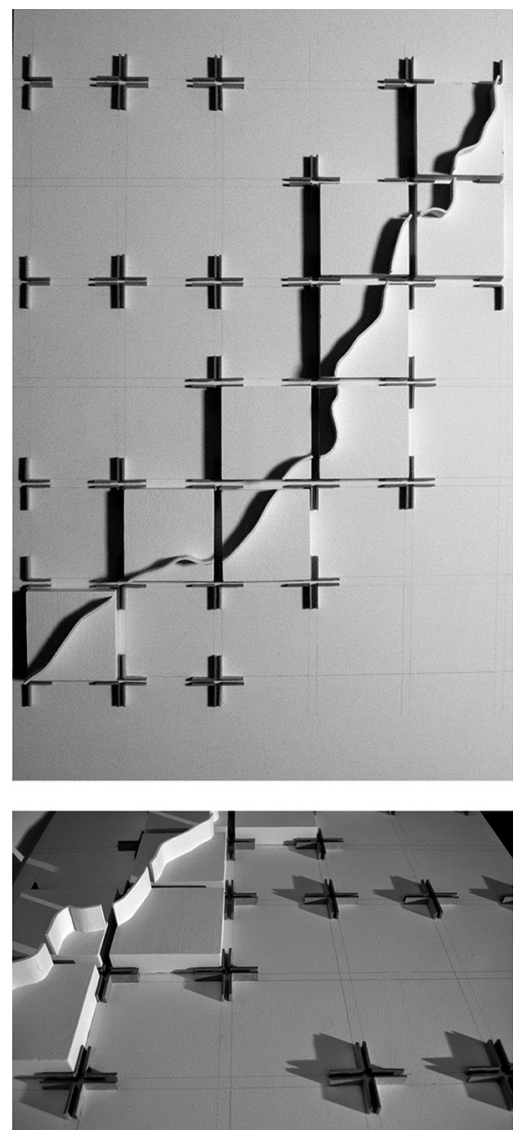

Figure 2. CS1 Site Analysis Model 
commuters, New York City “....where 40 percent of the 8.3 million residents spend at least 45 minutes in the car." Kansas City, like other American cities, has slowly engulfed individual towns to become a sprawling metroregion spread over two states. The greater metropolitan area is 7,855 square miles of land, with a little over 2 million residents, with a density of about 255 residents per square mile (compared to Manhattan which has over 70,000 residents per square mile). One reason Kansas City is of such low density is because of the incremental conversion of farmland to suburbs. Since its founding, Kansas City has been a resource hub due to its location at the convergence of the Kansas and Missouri Rivers. What began as a re-stocking station for wagon trains headed west became a network of outposts between farming

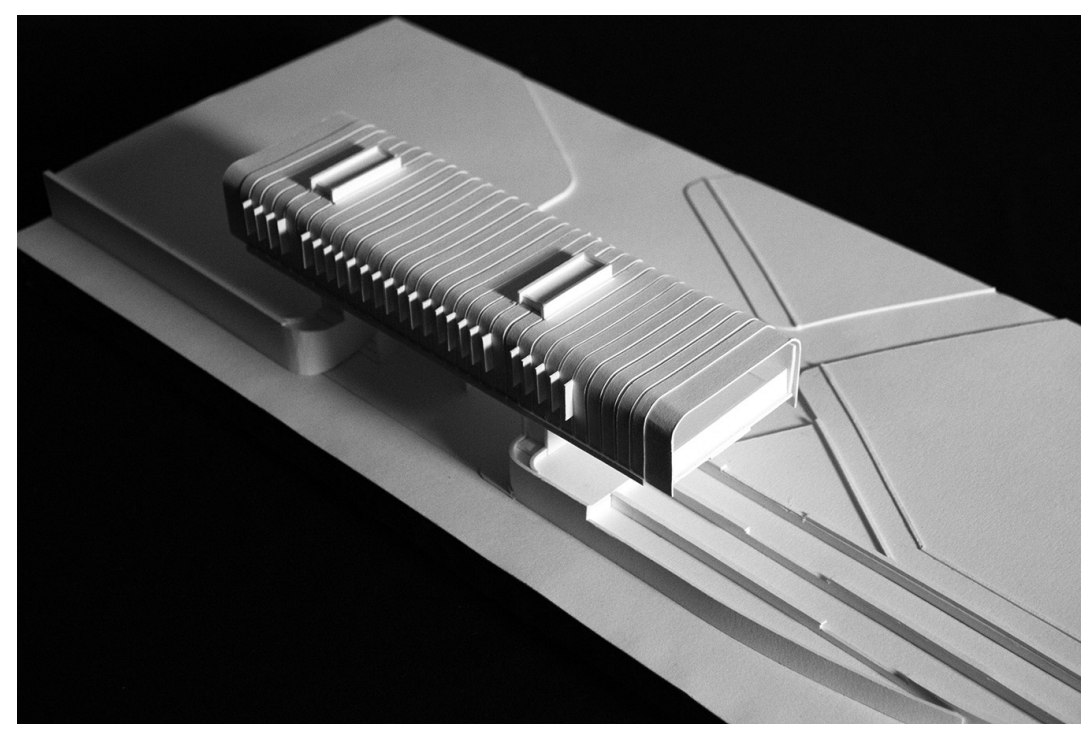

Figure 3. CS1 Model communities that served homesteaders and traders.

In the Midwest, property is laid out on a mile-by-mile grid. Historically, farms were allocated according to this grid, and today major roads still illustrate this principle. Disrupting this grain are natural waterways, which follow remnants of the original topography. Kansas City's hinterland rests on a complex network of tributaries, streams, and creeks. Over time, this led to the channelization of natural streams that integrated these with

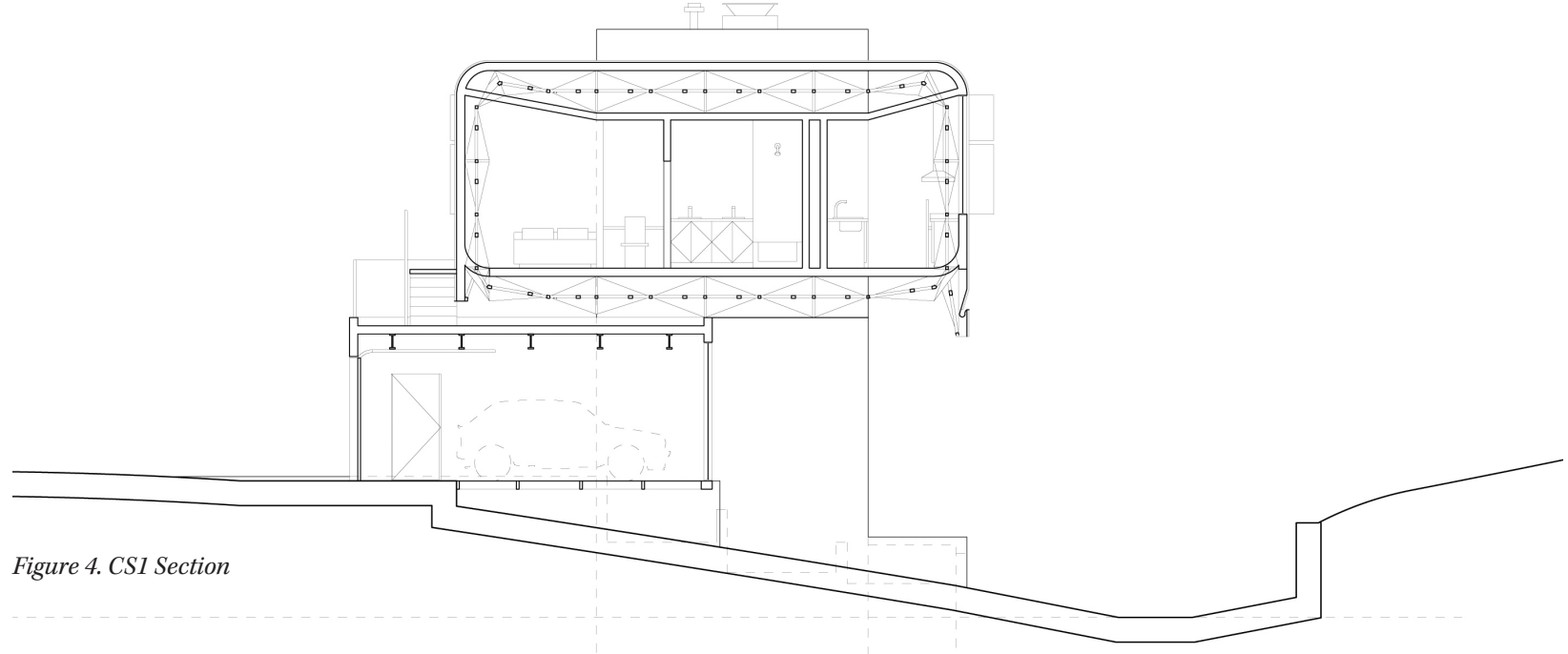

the storm sewer system. Analytical Model One illustrates the meander of streams against this grain, specifically a stretch at the beginning of Brush Creek, which becomes more volatile near the Plaza before making its way to the Big Blue River, and on to the Missouri. Significantly, and because these streams work against the grain of the suburbs and safely removed from automobile traffic, these open storm sewers now act as fair weather jogging and dog walking paths, opening up the possibilities for impromptu public space.

CS1 claims a fragment of property that exists at the intersection of the natural and artificial in this suburb. Because the streambed and topography naturally channel water from southwest to northeast, this cuts against the grid of the city. The stream is essentially a concrete-bottomed open-air storm sewer, which is channelized within gabion walls. This system is maintained by the city but runs through individual homeowners' lots, creating an easement condition that exists due to mutual benefit. The existing site is on a culde-sac planned for the neighborhood, which terminates with an odd driveway condition that serves as an access point to the stream. This

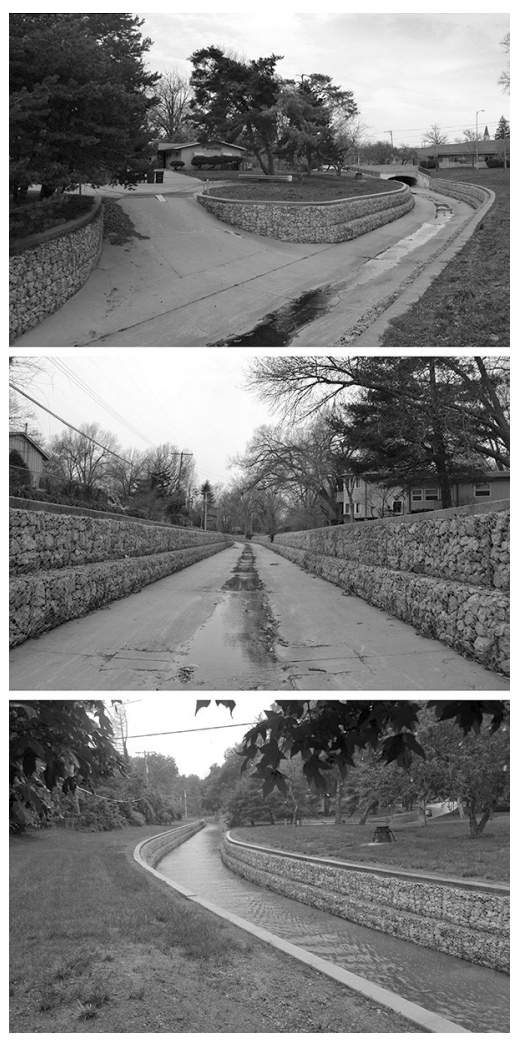

Figure 5. CS1 Site Photos

creates a peculiar lot condition for neighboring homes, where, similar to an easement, this land is maintained by the neighbors as an extension of their property. The challenge of CS1 was to negotiate the intersecting forces at work on the site-could the cul-de-sac be completed with a house that left the access road to the 
channel maintained, and accommodated this improvised public space for pedestrians?

Without igniting a neighborhood teardown, our intention was to create a model of contemporary suburban living that could act as a catalyst for the neighborhood. The house needed to walk the line between the competitive convention of real estate figures and construction method, considering the programmatic needs of modern living in the region, an alternative relationship to public and private space that promoted active stewardship with the site, experimental construction methods that could launch new standards in construction, and an architectural presence that did not rely on nostalgic and consumable finishes/ styles. Our intentions for the site were to build on what was there, taking advantage of any structural potential inherent in the existing infrastructure. The main level of the house is situated 12 feet above the street level, structurally suspended from two concrete cores. This maintains pedestrian and vehicular entry to the stream, while the two jetties of soil and gambion walls adjacent to this road are reconstructed to provide a pedestrian stairway to the stream, storm shelter space for the home, detention ponds and cisterns for runoff/overflow from the stream, and a ground-source heat exchanger that takes advantage of the cave-like qualities of the underground storm sewer system. The main living level sits within a steel space-frame tube that is cantilevered off the structural cores. The wall and roof cladding em-

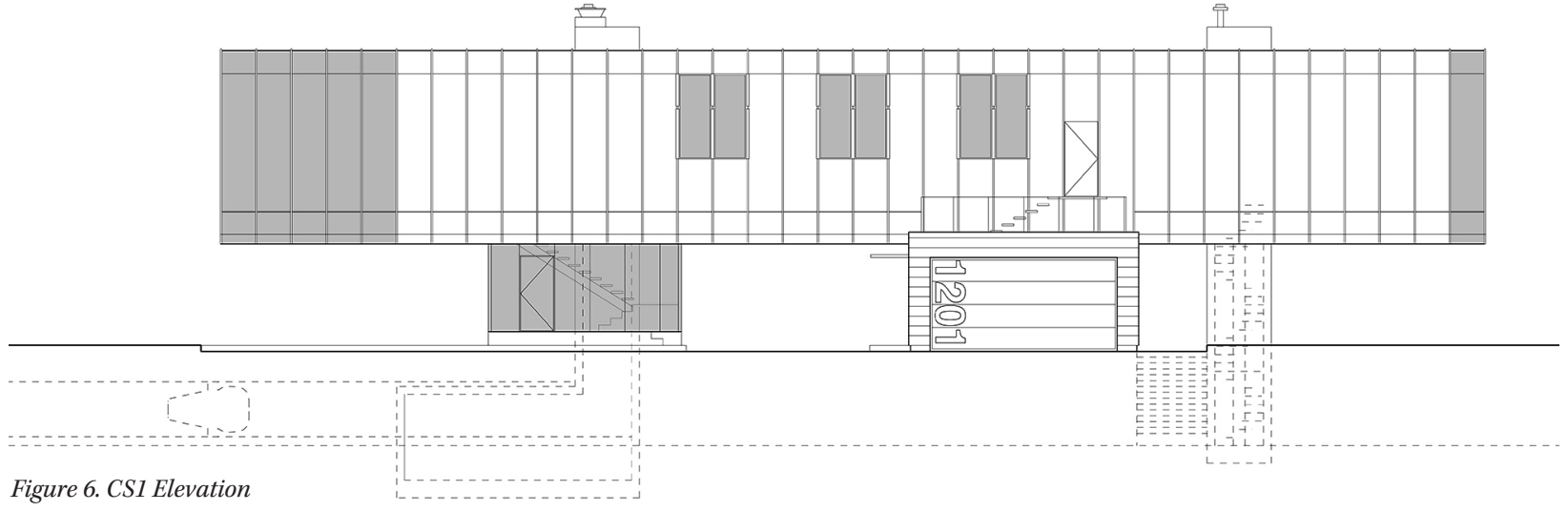

roof system that accommodates apertures for windows and which ultimately transitions to a metal mesh at the outdoor living spaces. The floor is also a SIP system that sits above the space frame, exposing the structure under the house. An integrated guttering system provides for rain catchment and an ambiguity in the reading of the structure as a tube or a bar. The main level is programmed around a central utility hub between the structural concrete cores that supply the utilities to the house. The kitchen, 2.5 baths, and laundry all reside in this central zone, and 3 bedrooms branch from this zone. Two larger living spaces exist on either end of the house for entertaining and for more informal private activities. The house is not a sealed tower: each of the larger living spaces and the master suite break out into an outdoor living area that is screened from neighbors, but intended to be semi-private. The transition from front to backyard is vague; it is a transitional semi-public space-the house effectively has no front or back.

\section{Case Study Two (CS2):}

\section{Albuquerque - Princeton Pump}

Like Kansas City, Albuquerque is a city made of a large network of aging and newer suburbs. The city's origins are distinct: it was a Spanish city for far longer than it has been an American one. Following Span- ish land grants, Albuquerque was formed around an integrated irrigation distribution system of acequias and their resultant land plats that created long rectangular lots assuring access to water. The railroad brought tourists and prospectors to the state, reinforcing the myth of the Frontier and crystallizing a regional architecture that merged Puebloan, Spanish/Moorish, and Mexican building strategies. With statehood, and later the introduction of the highway systems, came the motto that can be read on New Mexico's license plates-the "Land of Enchantment." The open road, the automobile, and the quest for adventure are wrapped into an idea about the American dream that defines how Albuquerque evolved from its Spanish origins. Route 66 provided the path, and Albuquerque became a stop along the way: fill your tank, spend the night, maybe stay. Route 66 brought the "American City" with it: the dream to own a house, a yard, a car. During and after World War II, Albuquerque experienced a housing shortage, partly due to the U.S. Military battling to harness the atom. To quell this shortage, contractors and architects developed regional house patterns that created a network of close-packed suburbs in the city.

Albuquerque is also a desert town: water is not always a life-giving resource. Flooding in the Rio Grande valley led to large earthwork projects and later to damming the river itself. As the population boomed, the city grew out of the river valley floodplains and onto the mesas leading towards the foothills. Floods came not only from the river, but from the mountains: flash flooding created dramatic shifts in the urban landscape, periodically eradicating whole sections of the city, which led to large projects to control the flow
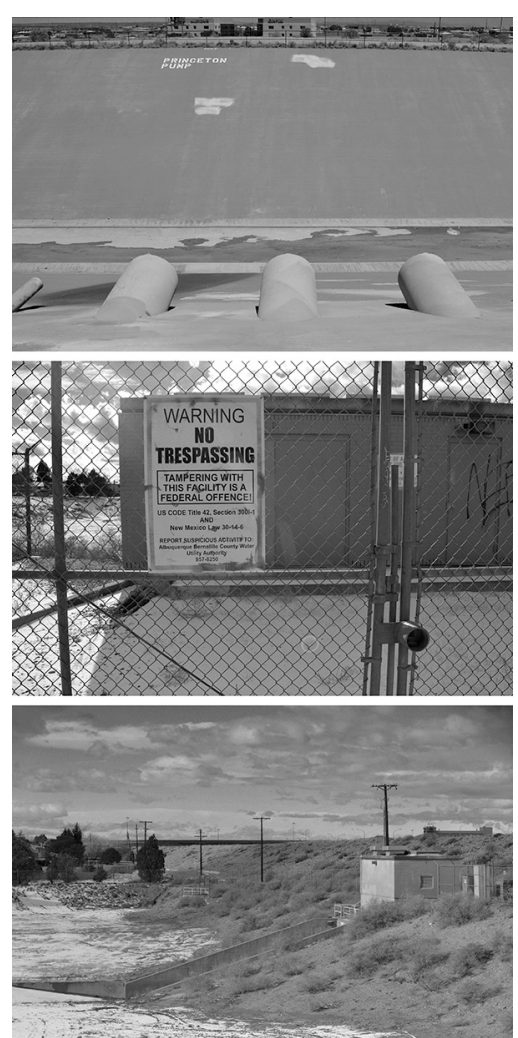

Figure 7. Case Study Two (CS2) Site Photos 


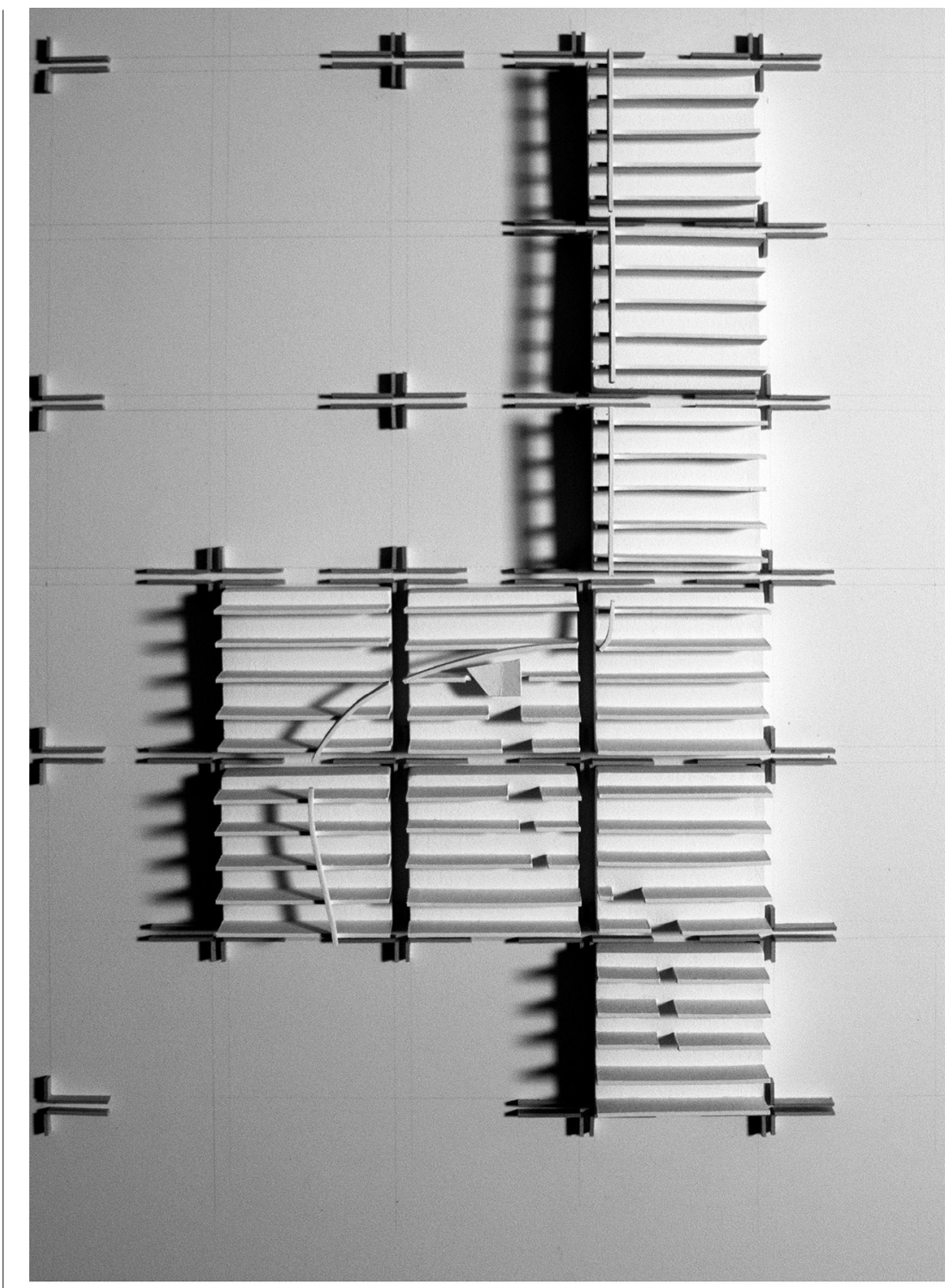

of water from the foothills. Two large open air concrete arroyos act as communal gutters for the city, catching the rainfall from the mountains and mesas and channeling it to the Rio Grande north of the city. The city's water systems are the result of a continuous evolution, highlighting the conversion of a developed agricultural landscape into an urban fabric, and the conversion of the natural landscape into built form. One distinct erasure still visible today in the suburbs that grew over the mesas is the conversion of the arroyos. Not dissimilar to Kansas City, the natural conveyance systems for storm water in the area were directly built over. While Albuquerque's street grid is an amalgam of the American mile-bymile grid alongside the vestiges of the Spanish land grant acequia system, the topography and dry streambeds still provide resistance against the subdivision development between principle boulevards.

CS2 resides on the terminus of a converted arroyo within a typical subdivision of Albuquerque. This sub-

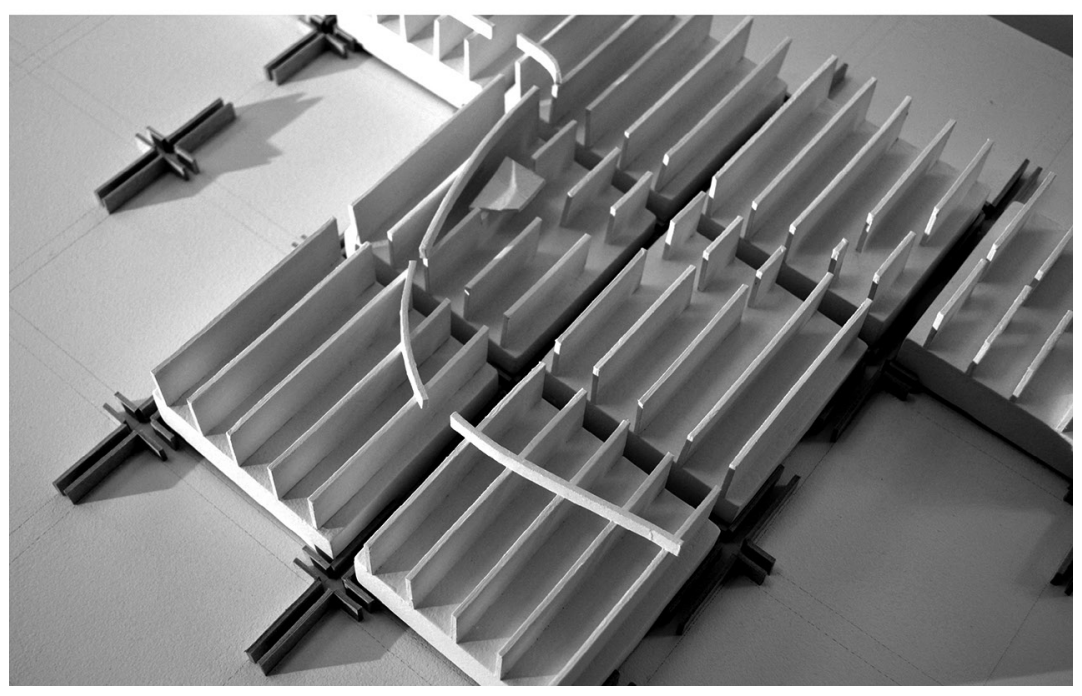

Figure 8. CS2 Analytical Site Model

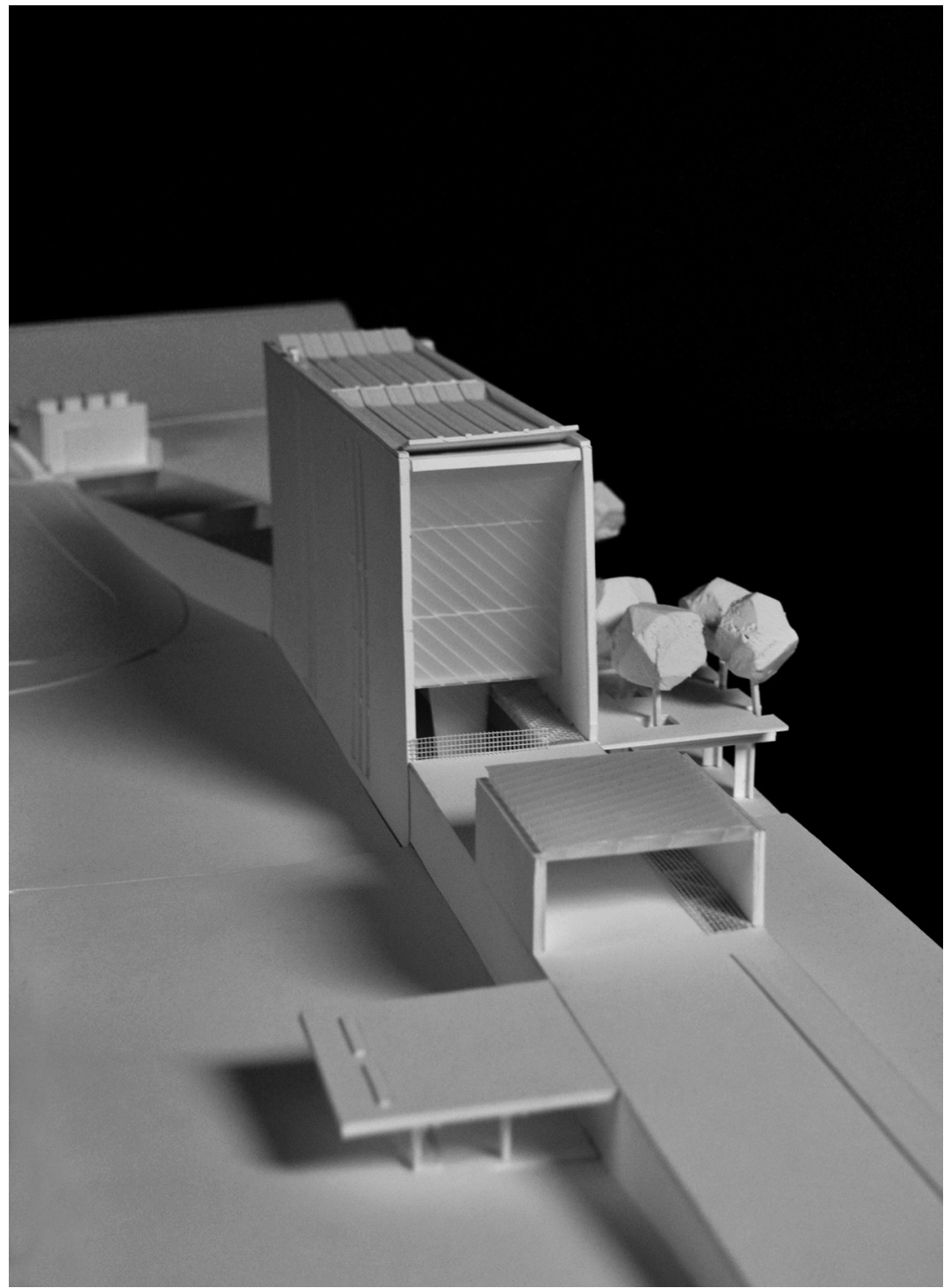

Figure 9. CS2 Model 
division accommodates the storm water that surges through the area by using the street as a dry gulch, and an underground storm sewer parallels this path. This subdivision also backs up against the large earthen levee of one of the city's concrete arroyos/gutters. The terminus of the converted arroyo is a large detention basin, plugged by the levee of the concrete arroyo. At the end of this catch basin, a large pumping station (Princeton Pump) delivers water vertically into the concrete arroyo. The site plan illustrates this large fenced-in, park-like void. Like CS1, residents have appropriated the area adjacent to this site as a path connector to the top of the levee/ arroyo to jog and walk their dogs. Again, the challenge for this house as with CS1 was to negotiate the intersecting forces at work on the site. The scale of this fragment of land was radically different from CS1, and the amount of water flowing during a flood situation was much greater.

Regional climatic conditions drive the scheme. CS2 appropriates the Princeton Pump and connects it with the open-air basin inlet at the street. Parallel concrete walls bridge from the inlet, providing water storage beneath the elevated driveway that sits at the maximum water level of the basin. These walls are extruded and become the house while simul- taneously providing thermal mass as protection against severe temperatures. Twin water tanks are embedded within the house, storing water collected from the roof to be used in the elevated garden and pool. $\mathrm{Hu}$ midity is funneled from above and below to cool the house. Residents of CS2 have a direct role as stewards, monitoring water levels and the Princeton Pump. Like CS1, CS2 accommodates 3 bedrooms and 2.5 baths, but the house is organized on 2 levels with a central utility core, so that the kitchen, baths, and laundry all are in relationship to the airshaft and overflow for the twin tanks. The lightweight diagrid rooftop water tanks are clad in translucent acrylic and filter light throughout the house while the roof serves as a double skin that opens to provide cooling, and that can close to act as an additional air barrier.

Like the 1950s Case Study House projects, the homes illustrated here are intended to provoke discussion, to think through the limits of what might be achievable in unforgiving conditions. They are also meant to question the things we take for granted in our neighborhoods, in our cities, like the power of flash flooding and the infrastructural measures that have been put in place to protect property and life. Architecture has a part to play in this: placing buildings in the environment manipulates and alters that environment. Perhaps the suburban ideal that is so quintessentially American should not be so quickly abandoned in favor of the densification of our cities, when most major cities' infrastructure cannot cope with disasters leading to an even greater loss of life and property. We must transform what we understand as a suburb, from a manicured lawn-scape to a cultivated landscape that works with its environment, and readdress the need for public space, not just the visual presence of the lawn but the built, articulated fabric we share.

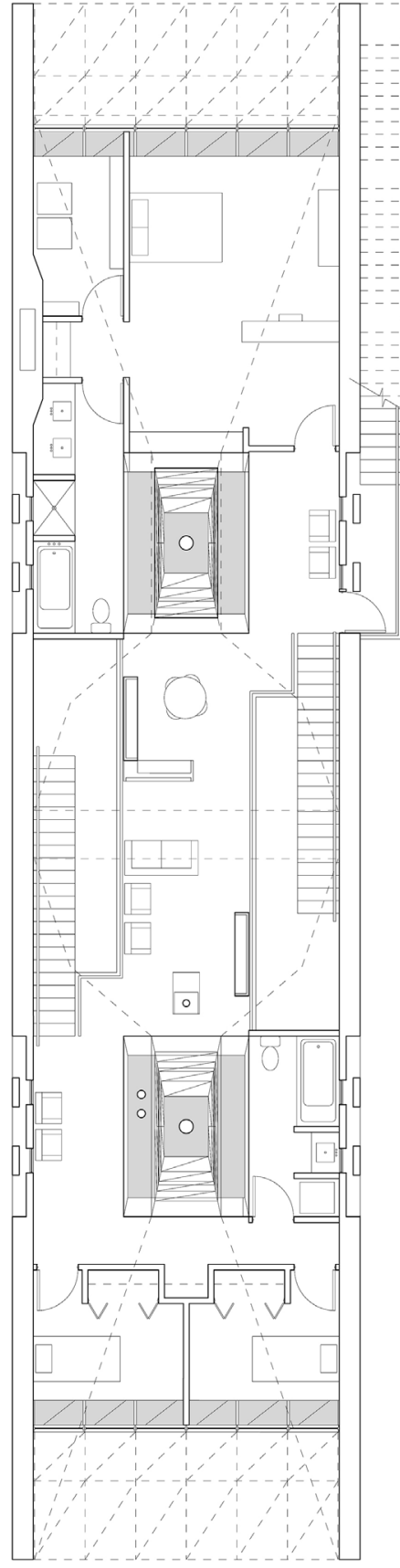

Figure 11. CS2 Plan

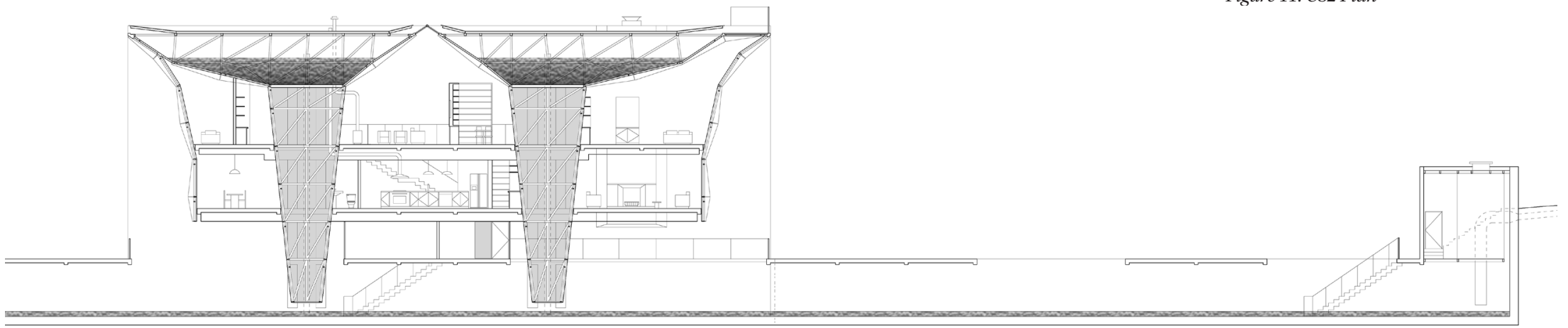




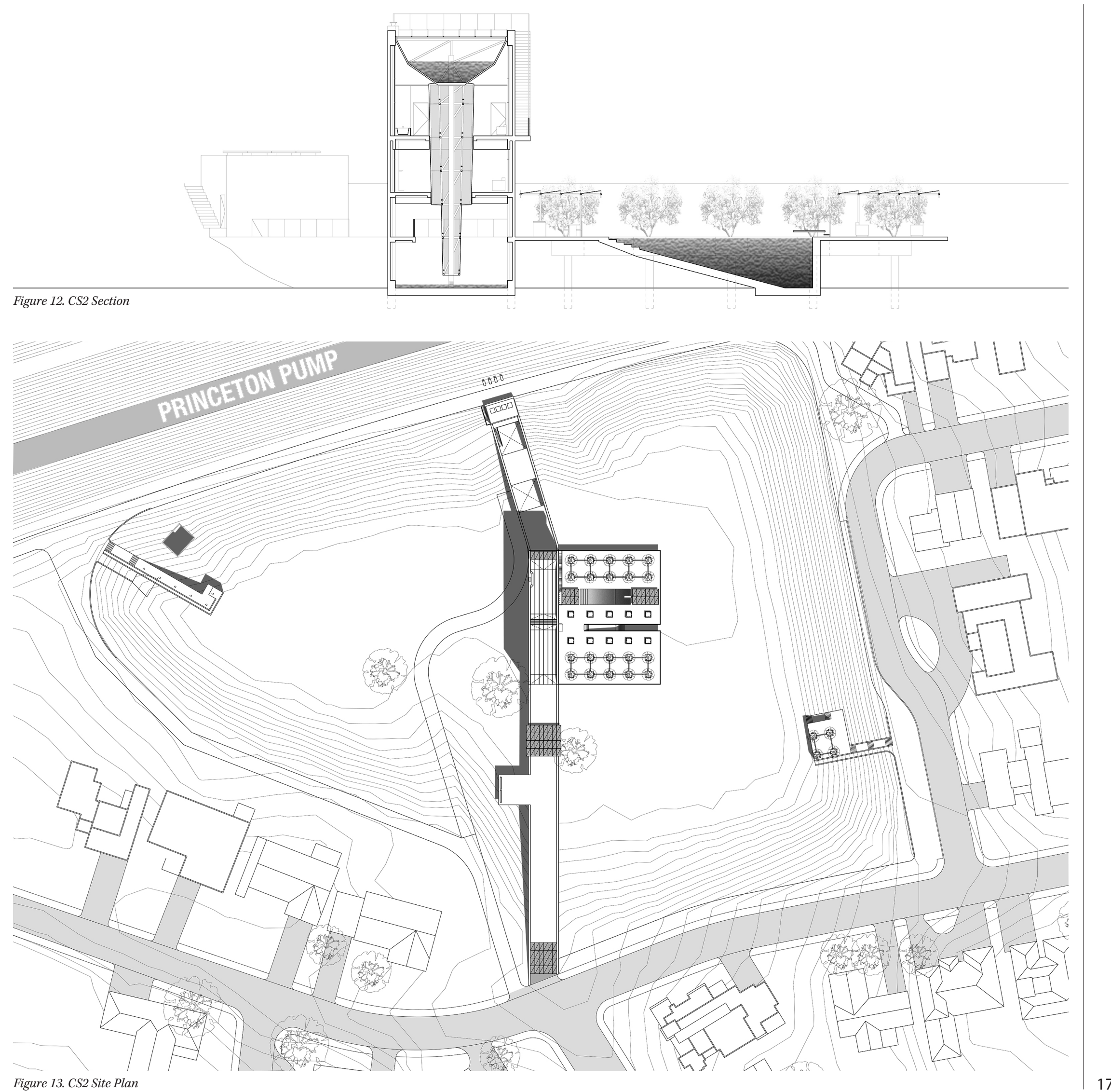

